\title{
Marine Fishing Management Towards Sustainability in Sierra Leone
}

\author{
Brima Massaquoi ${ }^{1}$, Nathan J. Roberts ${ }^{2}$, Gang Tian $^{1 *}$ \\ ${ }^{1}$ College of Economics and Management, Northeast Forestry University, 26 Hexing Road, Harbin 150040, China \\ ${ }^{2}$ College of Wildlife and Protected Area, Northeast Forestry University, 26 Hexing Road, Harbin 150040, China
}

Corresponding Author Email: tiangang0451@ sina.com

https://doi.org/10.18280/ijsdp.160514

Received: 1 July 2021

Accepted: 3 September 2021

\section{Keywords:}

fishing trade, marine fisheries, policy management, sustainable fishing, governance, social benefits, environmental policy, marine biodiversity

\begin{abstract}
Achieving global goals of eradicating hunger and poverty before 2030 requires improved resource management. This research analyses the historic use of marine fish in Sierra Leone from 1976 to 2019, captures original data of local market access, profit and waste in 2020, and presents worldwide case studies and a new transferable framework to assist national authorities and managers to increase food security and improve management, achieving related Sustainable Development Goals (SDGs) through policies, technology and economics. Fish catch, export and Catch Per Unit Effort (CPUE) data from FAO FishStatJ, fisheries ministry and secondary sources, and 218 surveys of marketplace fish sellers, were analysed by simple descriptive and comparative statistics. Total fish catch increased substantially in recent decades, while CPUE fluctuates and declined between 1999/2000 and 2010. Many fisheries are exploited or overexploited and market sellers commonly do not have access to enough fish. Exports are consistently low. Case studies in developing and developed countries demonstrate that resolutions are three-pronged: improved awareness of environmental impacts, laws and policing; science and technology utilisation in monitoring resources and fishing activities, and establishing best practice, and; international cooperation, agreements and fair use policies. Priority should be given to unite government and community fishing relationships.
\end{abstract}

\section{INTRODUCTION}

Eradicating hunger and poverty are two fundamental targets integrated into the United Nations Sustainable Development Goals (SDGs) endorsed by 193 nations in 2015 [1, 2]. Meanwhile, food demand has increased more than ever before, across the breadth of the agriculture sector and food pyramids [3]. Due to the growing human population and shortcomings of current global food systems [4], there is urgent need to progress towards sustainability, thereby ensuring food security.

Sustainability is having enough food to eat, today and for future generations; it is the ability to achieve long-lasting maintenance of human societies and natural ecosystems without the depletion of resources, and is at the centre of delivering social, economic and environmental benefits. Sustainability is also about innovation, utilising alreadyreduced resources wisely and efficiently, promoting restoration, and taking the environment and ecology into consideration $[5,6]$. Remarkable progress towards these goals has already been achieved in few short decades, including in several notable developing countries, such as China [7], Chile, and the Gambia [8]. Most nations are now ambitiously striving to end hunger and poverty by 2030 .

Sierra Leone is well known around the world for its abundance of natural resources, such as minerals, agriculture, forestry and marine resources, which historically attracted interest and generated income for both the colonial master and the indigenous peoples [9, 10]. During the 19th century, agricultural exports from Sierra Leone were well recognised among Sub-Saharan countries [11]. A national legal marketing body even came into effect in 1949 responsible for the purchasing, importing and exporting of Sierra Leone's agricultural products [11]. However, around this time a shift occurred, as the value of agricultural products gradually declined and people left the agriculture sector to move into the more economical mining sector for diamond [11].

After gaining independence from their British colonial master in 1961, Sierra Leone - like other newly-independent African States - failed to make the "great leap forward" and take its rightful place among the rising democracies of the 1960s [11]. Problems started within the decade, propelled with corruption, bad governance, nepotism and partisan, resulting in the country receiving little benefit from the natural resources. Subsequently, eleven years of civil unrest ensued from 1991 to 2002, creating a fragile state. During this period, people were displaced from rural communities as they migrated to urban areas, agricultural development and economic activities became disengaged, and local land rights were lost, threatening livelihoods and food security [9]. Thus, poverty and hunger is incommensurable in the country and up to now the country is still facing these challenges, dependent on imports even for basic commodities the country is ecologically capable of producing domestically [12].

The tropical climate and rich soils favour agricultural production in Sierra Leone on land and at sea, but the government is currently not paying adequate attention to the sector [13]. An engaged agriculture sector, however, gives hope for the country's economic development and food security, and renders a multitude of benefits for sustainable development in contrast to the extraction of minerals [14]. 
Developing sustainable solutions for various areas of the economy requires diversification and taking risks of innovation to stay in the market and achieve economic growth, especially considering consumer values in environmental responsibility and demands of a growing, wealthier human population [15]. With great awareness and attention to end hunger and poverty, many researchers have offered solutions [16]. Broadly in the case of Sierra Leone, government, NGOs and other donor partners should actively engage in nationally harmonised agriculture and aquaculture systems which (when managed appropriately) are environmentally and economically sustainable, including agreeing standards and regulations from parliament, and securing adequate economic support and stakeholder engagement.

Globally, fishery resources are in decline [17]. The proportion of stocks which are overfished has near continuously increased between 1974 and 2015 and the available stocks which are underfished (i.e., those not fully exploited) has near continuously decreased in the same period [17]. In 2017, biologically sustainable fish stocks represented $65.8 \%$ [18], divided as 'maximally sustainably fished' plus 'underfished' [17]. Of the 17 internationally-agreed SDGs, SDG14 aims to ensure the sustainable use of the seas, oceans, and marine resources [1], and SDG 14.4 specifically targets to end overfishing by 2020 . Overfishing continues to increase (though at a lesser rate), and corrective performance is vastly inadequate, falling far short of what is required. Effectively, $93 \%$ of global fish stocks were fished at maximum capacity (approximately 59\%) or overfished (approximately 33\%) in 2015 [17]. If the world is to benefit from fisheries sustainably, damage from human activities must be alleviated [19], including protection of the marine environment supported by well-enforced laws which control Illegal, Unreported and Unregulated (IUU) fishing and pollution, the adoption of an ecosystem approach to management, and climate change mitigation and adaptation, among other measures [6]

Climate change, as a result of unsustainable human activity, poses to further threaten marine fish resources, with the ocean absorbing more than $90 \%$ of excess heat resulting in ocean warming, driving a global $4.1 \%$ decline $(1.4$ million metric tonnes) in maximum sustainable yield between 1930 and 2010 [20]. Although changes in catch are likely to vary by latitude (including as a result of warming-driven shifts in animal distributions [5]), reduced ocean productivity and catch potential due to climate change will add more pressure on marine-dependent communities such as those in West Africa, affecting income, food security and nutritional health [21]. The recent scientific report from the Intergovernmental Panel on Climate Change (IPCC) makes unquestionably clear that global society must reduce greenhouse gas emissions in order to keep to $1.5^{\circ} \mathrm{C}$ of global warming above pre-industrial levels through the century [22]. As a fuel-intensive activity which contributes around $4 \%$ of food production emissions [23] and has seen a 4.1- and 5.8-fold increase in emissions from industrial and small-scale fisheries, respectively, since 1950 [24], fisheries should be part of emission reduction strategies.

This study analyses marine fisheries resource use in Sierra Leone because it is a nationally important source of economic income and nutrition (protein). The objectives of this study are to compile original and secondary data from a range of local, national and international sources on the present and historic use of marine fish resources in Sierra Leone to provide context and rationale for sustainable use, and to identify and present diverse solutions, case studies and a model for their adaptation to demonstrate evidence of successful implementation and to assist responsible authorities in Sierra Leone and other countries to improve resource management towards achieving related SDGs; for Sierra Leone, we have prepared this work as a navigational map to help the Ministry of Fisheries and Marine Resources (MFMR) achieve sustainability if followed.

\section{METHOD}

\subsection{Literature review and secondary data}

Reviewed literature principally included academic research, publicly available government documents, and authoritative websites such as United Nations and its agencies. Case studies presented in this article have been evidenced to have had positive outcomes and are considered here to be easily replicable in Sierra Leone and other countries following an adjustment/correction process (described in 3.2).

Primary longitudinal data of marine fisheries resources and their use in Sierra Leone is notoriously difficult to obtain, and secondary data is both limited and likely distorted and somewhat fails to represent truth [25]. Despite these limitations, we aim to present the best-quality data available, including total marine fish catch data in Sierra Leone from 1976 to 2018, extracted from the Food and Agriculture Organisation of the United Nations (FAO) FishstatJ database [26], expanding on the work of Seto et al. [27]. We also present Catch Per Unit Effort (CPUE) data from secondary sources [27-30] to gauge trends in fish availability over time as a proxy of fish stock, for which measurements were unavailable. This is supplemented by the additional presentation of marine fish export data for the same period, sourced from FAO FishstatJ and independently from MFMR (2016 and 2019 only). This chosen study period not only represents the full extent of the FAO dataset for fisheries production and trade, and most of the capture production dataset, but is also selected to reflect on a duration length in which alleviating poverty and hunger in a developing country is demonstrably possible, as accomplished by China, for example [31].

\subsection{Local fish market questionnaire survey}

To understand local-level access to fish, profit and waste, and to identify common challenges and potential improvement measures, we designed a simple 10-question online questionnaire (www.surveymonkey.com) which was delivered in-person on a mobile device at three of the largest fish markets in Sierra Leone: Tombo (Western Rural), Goderich (Western Urban), and Kissy dockyard (centre of Freetown). These market areas are highly populated (especially Tombo and Goderich), represent an important distribution centre for both domestic and foreign fishing stocks (Kissy dockyard), and are geographically significant for the distribution of marine fish to the national population inland.

The survey was completed between November 2020 and January 2021, with a pilot study undertaken in October 2020 to test and refine questions. Although there is some temporal misalignment between these data and the other sources mentioned above, food security is an historical issue in Sierra Leone spanning decades, and we consider this sampling disparity acceptable here. Respondents were female market sellers because: (1) market sellers are assumed to have more knowledge about fish availability, profit and waste, etc., than 
does the general population, and; (2) women are more involved in local trade than their male counterparts (who are typically involved in the fishing activities).

Recognising that precise data may be difficult to obtain or estimate/recall, and may therefore, lead to false conclusions, for the purposes of this questionnaire research, we considered it reasonable and sufficient to collect categorical data for all questions except two open-ended questions on motivations and challenges. Besides simple descriptive statistics and qualitative summaries of open-ended questions, we were also interested to investigate any potential relationships between categorical variables, analysed in RStudio Version 1.3 by Chisquared contingency analysis with Monte Carlo simulation (based on 2000 replicates) to account for small sample size.

\section{RESULTS AND DISCUSSION}

\subsection{Situation in Sierra Leone}

\subsubsection{Fish Stock, Catch and Catch Per Unit Effort (CPUE)}

Many marine fish stocks in Sierra Leone are fully exploited or overexploited, according to an FAO/CECAF Working Group report [13]. There is also strong evidence that overfishing has led to scarcity across the Gulf of Guinea [1]. Hence, it is already apparently clear for the need to urgently restore overexploited fish stocks and to ensure sustainable management in this region.

It would of course be helpful to know how many fish there are in the sea and to monitor status and trends over time, signaling further depletion, stability or recovery. Proper, standardised and replicable stock assessments are incredibly valuable (and advised) to inform evidence-based decision making and adaptive management. In the absence of such assessments, as in Sierra Leone, Catch Per Unit Effort (CPUE) may offer a proxy [32]. Five expert CPUE assessments undertaken in 1977, 1987/1989, 1999/2000, 2010 and 2015 are presented (Figure 1). Values have fluctuated over these decades with a peak in 1999/2000 followed by a distinct sharp decline to 2010 which may correspond with the considerable increase in total catch. Although the CPUE assessment in 2015 may suggest some recovery or stability, a re-assessment in 2020 (or the earliest opportunity thereafter) following the same methodology as in earlier decades would be of significant value, specifically in order to investigate whether indeed CPUE can be equally high now as in the late 1980s despite total catch being more than five times higher today than then.

Official fish catch data from FAO for the period 1976 to 2018 are presented (Figure 1). Due to large discrepancies between different sources of information in Sierra Leone [27], these data are assumed to be largely conservative and should be considered as an underestimate. Trends however, may at least signal cause for responsive action or indicate effects of implementation measures. The one month ban introduced in Sierra Leone in April 2019 [33], for example, is expected to be reflected in the 2019 data as reduced total annual catch, assuming it was not compensated for in other months. These data were unavailable at the time of writing in 2021, but could potentially later help us to explore short-term effects on catch statistics, including any reduction or compensatory effects. Longer-term, we may be able to use CPUE measurements to evaluate effects of fishing bans, as in Torre Guaceto, Italy where a well-implemented ban increased fish productivity - an evidenced success. Additionally, it is worth considering total catch in relation to human population size, realistically evaluating whether demands can be met and sustained for an increasing (and increasingly demanding) population and planning appropriate sustainability measures to secure longterm fish stocks and food security [34].

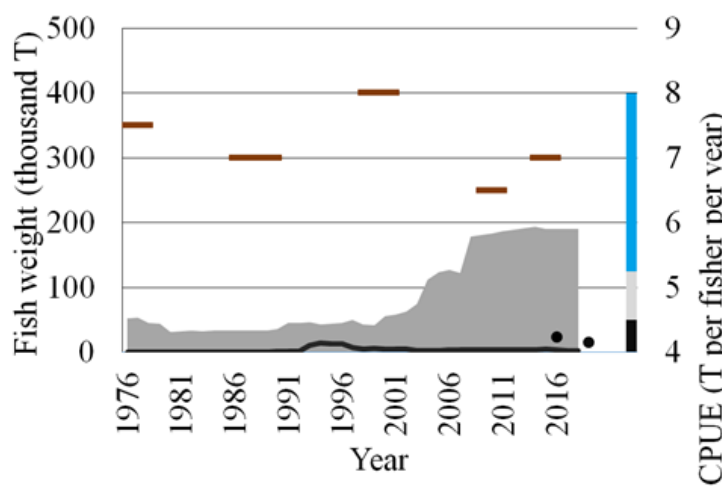

$$
\begin{aligned}
& \text {-FAO FishstatJ Catch } \\
& \text {-FAO FishstatJ Export } \\
& \text { - MFMR Export }
\end{aligned}
$$$$
\text { •Foreign illegal }
$$$$
\text { Foreign legal }
$$$$
\text { -Catch Per Unit Effort }
$$

EDomestic

Figure 1. Marine fisheries fish catch, catch per unit effort (CPUE) and exports from 1976-2019. MFMR is Ministry of

Fisheries and Marine Resources. The inset column (right) shows total catch in 2015 by foreign and domestic fleets [27]; note the descrepancy compared with the FAO FishStatJ catch data

For transparency and clarity of catch data, and to consider in resource management decisions, it should be emphasised that between 1990 and 2015 foreign legal and foreign illegal fishing have reduced, whilst domestic fishing has more than doubled. Respectively, total catches in 2015 were approximately $75,000,50,000$ and 275,000 tonnes [27]. It is therefore, likely advisable that the MFMR should pay particular attention to domestic fishing based on catch figures.

\subsubsection{Exports}

Marine fish exports are an important part of a comprehensive resource management plan. The data presented from FAO and MFMR (Figure 1) reflect that exports are very low and relatively consistent (except for the peak during the civil war), despite the huge increase in fish catch in the recent decades and the discrepancy between the two sources in 2016 and 2019. Data of countries receiving fish exports (Figure 2) reveal principal trade flows, which can be used to advise and develop international trade relations, including determining export quotas. In 2016, China, South Korea, and Ghana were the highest importers of marine fish from Sierra Leone, excluding 'other carriers' for which the country was unspecified. These countries were also among the top four in 2019. Though data for economics and development are not presented, analyses beyond the scope of this paper could be performed to evaluate (and maximise) economic benefit of export, division of benefits from government to local communities, and whether export is aiding or hindering development in Sierra Leone or simply satisfying external business and trade obligations and agreements. 


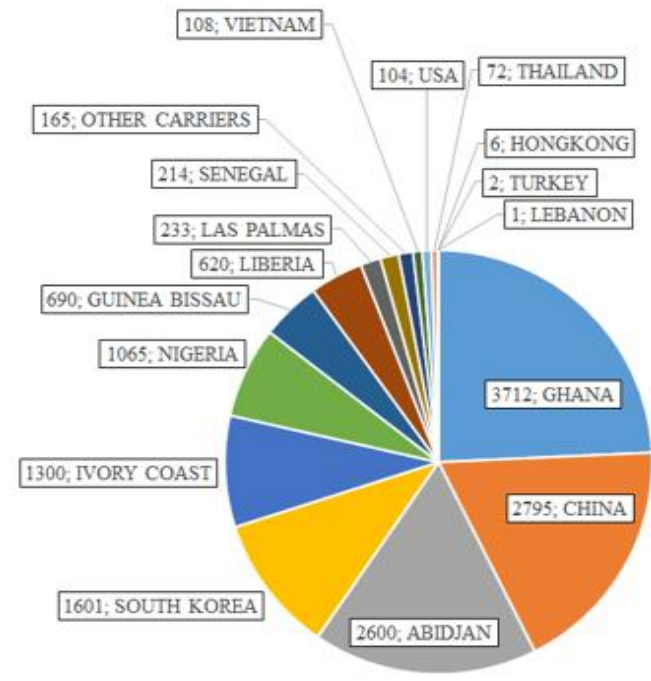

(a) 2016

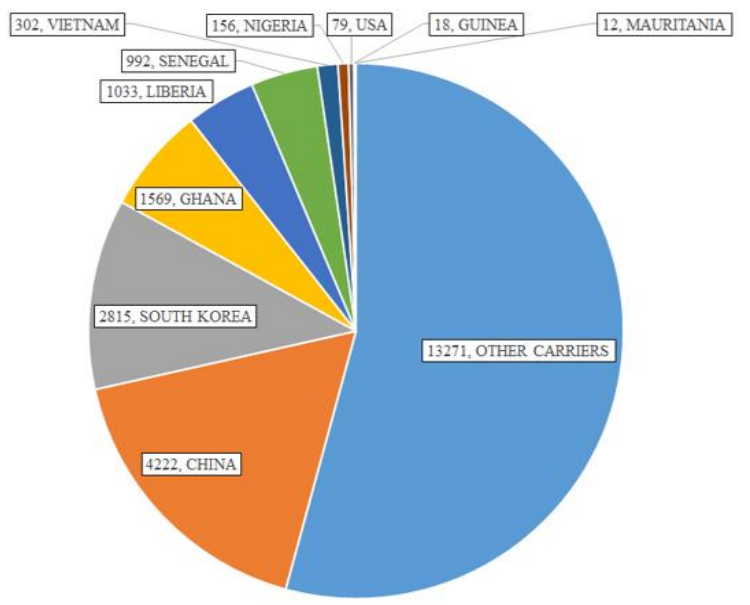

(b) 2019

Figure 2. Marine fisheries recipient countries for 2016 and 2019 exports and respective total fish catch weights (tonnes)

\subsubsection{Local fish trade}

A total of 218 fish sellers in Tombo $(\mathrm{n}=115)$, Goderich ( $\mathrm{n}$ $=58)$ and Kissy dockyard $(\mathrm{n}=45)$ markets participated in our survey. More than $32 \%$ of the respondents had been selling fish for 15 years or more, and hence have much experience to contribute to this research and, in working together with the central government, can be considered a valuable player in overcoming challenges and finding long-term solutions.

The common reasons for respondents to sell fish were for important family or local heritage reasons, and that it is considered a fast way to achieve quality economic income, including for single parents. In a second open-ended question (the above being the first), some of the problems the market sellers faced were lack of storage facilities due to lack of electricity, and limited financial capital to continue trading. The logical resolutions could therefore, be the government prioritization of access to sustainable and reliable electricity (related with SDG7 Affordable and Clean Energy), and provision of loans. Micro-credits awarded to women is expected to result in micro-business success and reliable loan repayments, profiting government at low economic risk [35]. An additional, potentially related finding was that most market sellers $(68.32 \%)$ sell more fish in the dry season than in the wet season. During the wet season, fishing may become more dangerous and outdoor marketplaces less active for trading.
Seasonal differences in catch and profit should be investigated, and consideration given for investment in storage facilities and indoor marketplaces which may, we suspect, better support a more even seasonal distribution of income and marine-based nutrition for market sellers and consumers, respectively.

When asked whether they have access to enough fish, only $6.92 \%$ of market sellers responded 'all of the time'. Other responses were: 'most of the time' $(57.23 \%)$; 'about half the time' $(16.35 \%)$, and; 'rarely (less than half of the time)' $(19.50 \%)$. What's more, we found that access to fish varied between the three marketplaces $(p<0.001)$. More than a third of respondents $(35.80 \%)$ in Tombo market reported rarely having access to enough fish, compared with just $2.13 \%$ and $3.23 \%$ of respondents at Goderich and Kissy dockyard, respectively. Across the market places, 55.55\%, 70.97\% and $74.47 \%$ of respondents had access to sufficient fish 'all of the time' or 'most of the time' in Tombo, Kissy dockyard and Goderich, respectively. Evidently, accessibility to marine fish in these markets (and by reasonable extension, Sierra Leone) is an issue that the government and other developmental partners must work hand in glove to solve for the benefit of traders and consumers, as well as actively engaging fishermen in the improved distribution of fish across marketplaces. The remaining shortfall must be addressed through restoration of wild fish populations and better management of its capture.

Recognised by the market sellers as an important economic activity, respondents reported daily profits of less than 20,000 Le (7.14\%), 20,000 to 30,000 Le (23.38\%), 30,000 to 40,000 Le $(41.56 \%)$, and more than 40,000 Le $(27.92 \%)$. For important reference, SDG1 No Poverty has performance indicators at $\$ 1.90 \mathrm{USD} /$ day (approximately equivalent to $19,491 \mathrm{Le}$ ) and $\$ 3.20 \mathrm{USD} /$ day (approximately equivalent to $32,825 \mathrm{Le}$ ), suggesting that most market sellers are above the lower recognized poverty threshold, if not the higher threshold.

Concerning waste, $42.33 \%$ of respondents reported zero waste; others discard less than half $(34.39 \%)$, approximately half $(12.17 \%)$ or more than half $(11.11 \%)$ of their fish stock every week. Levels of waste were different between the three marketplaces $(p<0.001)$, as was the occurrence of zero waste $(p<0.001)$. Specifically, $27.45 \%$ of respondents in Goderich discarded more than half of their fish each week, compared with $10.00 \%$ and $3.06 \%$ of respondents in Kissy dockyard and Tombo, respectively. Secondly, Tombo market had higher occurrence of zero waste $(59.18 \%$ of respondents), compared with Kissy dockyard (37.50\%) and Goderich (13.73\%). Despite Goderich and Kissy dockyard having access to an electricity supply, and therefore, potentially cold storage, waste was more prevalent in these marketplaces. However, in this regard, the data revealed that having cold storage did not influence whether there was waste or not $(p=0.5617)$, and oddly resulted in variability in levels of waste $(p<0.001)$, with $25.00 \%$ of those with an ice box discarding approximately half of their fish each week, compared with $4.27 \%$ of respondents without such facilities. Wasting food is of course not a good habit by any measure, especially considering prevalence of hunger. Moving forward, food waste monitoring should be initiated within these communities, perhaps especially in Goderich, to find suitable approaches to minimise waste and reward high levels of zero waste such as in Tombo.

Finally, we found that $58.47 \%$ of respondents were selling smoked fish, compared with $40.98 \%$ selling raw fish and $0.55 \%$ selling both raw and smoked fish. Notably, we found that the type of fish sold (i.e., raw or smoked) was related with the amount of fish discarded each week $(p=0.007)$ as well as 
the prevalence of zero waste $(p=0.005)$. Specifically, $51.40 \%$ of smoked fish sellers reported zero waste, compared with $30.67 \%$ of respondents selling raw fish, and of those wasting fish, $69.23 \%$ of smoked fish sellers discarded less than half, compared with $53.85 \%$ of raw fish sellers. We suspect the reduced levels of waste observed for smoked fish sellers can be attributed to the extended shelf life. What's more, although the percentage of respondents making less than 20,000 Le profit per day was virtually the same for smoked fish sellers $(6.67 \%)$ and raw fish sellers $(7.94 \%)$, daily profits across the full spectrum were different between these two groups ( $p=$ 0.0065 ) with a near-significant difference between these two groups when comparing above or below the higher SDG poverty performance indicator value (i.e., 30,000 Le or more; $p=0.0525)$; it is probable that sellers of smoked fish have higher daily profits than do sellers of raw fish and are more likely to be above the higher poverty line.

\subsection{Emulating and adapting successful case studies}

There are numerous strategies and respective case studies of improved fisheries resource management demonstrated around the world that a country or administration can seek to emulate, such as by MFMR in Sierra Leone and in other developing countries experiencing poverty (Table 1). Yet, they will likely require some level of adaptation or correction to meet the specific needs, goals and circumstances of the management unit (e.g., country or resource area). As a framework to aid planners and decision makers in this process, we propose a transferable five-step process for the design, development and implementation of improved resource management plans (Figure 3a), and five principal correction factors (Figure 3b) which bear interrelationships with achieving targets across the breadth of the SDGs.

In this five-step process, the advisor/decision-maker begins by assessing the current situation of the resource and its use (step 1) and reviewing a range of relevant case studies, recommendations and observations (step 2). Potential candidate management systems identified in step 2 are then adapted to fit the conditions, needs and goals of the given situation (step 3), formulating a plan for trial implementation (step 4). The process ends with scientific monitoring, public sharing of results, and continuous adaptive management (step 5), routinely evaluating performance against scientific and meaningful indicators such as fish stock, Catch Per Unit Effort and standardized SDG indicators; it is important to adjust the implementation strategy as appropriate, and implement as an holistic long-term adaptive management plan. Expected outcomes from improved management (marked as ' + ' in Figure 3a) include achievement of SDGs, such as SDG1 No Poverty, SDG2 Zero Hunger, and SDG14 Life Below Water, and the collection and communication of scientific data and analyses which contribute to the important pool of case studies and current datasets to guide further evidence-based decision making.

When adapting case studies and recommendations in the management plan design phase (i.e., step 3), five principal correction factor themes should be considered: history; people; resources; governance and administration, and; foreign relations.

Table 1. Marine fisheries management solutions towards achieving sustainability goals

\begin{tabular}{l} 
Solutions \\
\hline 1. Trading systems and eco-labels [36] \\
2. Environmental awareness, peer-to-peer \\
education, scientific methods [37, 38] \\
3. Marine Protected Areas (MPAs) and \\
their governance [39] \\
4. Global Positioning System (GPS) \\
technology [41] \\
5. Security patrols and policing [1,37] \\
6. Global partnerships and building \\
intergovernmental and institutional \\
capacity [37, 42] \\
7. Fishing register, including quotas and \\
fishing bans [43] \\
8. Financing and subsidies [44] \\
9. Government and fishermen cooperation \\
[46] \\
10. Public communication and community \\
engagement [47]
\end{tabular}

engagement [47]

\section{Recommendations for Sierra Leone}

Organise a score-based assessment of fish stocks, environment and management [32]; Label sustainable stocks and products.

Invite experts to talk with officials of the Ministry of Fisheries and Marine Resources (MFMR) and locals; Build understanding and scientific capacity.

Management plans for MPAs should be produced by 2025 and a management committee set up within the MFMR according to Sierra Leone's Second National Biodiversity Strategy and Action Plan 2017 - 2026 [40].

Register all domestic and international vessels and their GPS units as a requirement of entering the Exclusive Economic Zone (EEZ); Provide science and technology training. Operate day and night patrols; Mobilise Navy and MFMR to secure the sea, including arrests of IUU perpetrators.

Understand and implement the agreements already committed to, such as the Fishing Partnership Agreement [37]; Rectify legal violations in the Gulf of Guinea, including the duplicity of the EU Common Fisheries Policy [37].

All vessels should be registered in a uniform, accessible format; Fishing quotas, including number of vessels and catch, based on science, policy and stakeholder agreement [40]. Eradicate subsidies that contribute to overfishing or support IUU fishing [45].

All parties involved in fishing should be aware of the importance of marine fisheries sustainability [46].

Use available communication channels such as TV, radio and mobile phone to inform communities about government plans for the transition towards the sustainability of marine fisheries.
(1) History is a set of experiences of the past, and may include independence, war, famine, and disease, and may help to identify potential preconditions, such as the collapse of food security and development in Sierra Leone in the 1970s/1980s which many link with the change in political landscape [11].

(2) Concerning people, a major challenge in Sierra Leone is illiteracy and unemployment, particularly of youth who lack skills and education and are largely disengaged [48]. The youth literacy rate is $66.6 \%$ [31] (adult literacy rate: $41 \%$ [48]) and $70 \%$ of youth are unemployed or underemployed [48].
Implementing any improved management measures must therefore, ensure that key messages are well communicated and understood within the population, such as government laws, Marine Protected Area (MPA) signage and fishing quota documentation, and mass public communications and consumer messages. Building quality education (SDG4) would likely have real implications on resource sustainability, as currently more than $80 \%$ of fishermen in Sierra Leone are illiterate and supposedly do not agree with the potential for fish stock depletion [25]. Better involving women and youth 
in the decision-making process would increase progress, inclusiveness and equality (SDG5) [49]. Moreover, authorities must consider public health and nutrition.

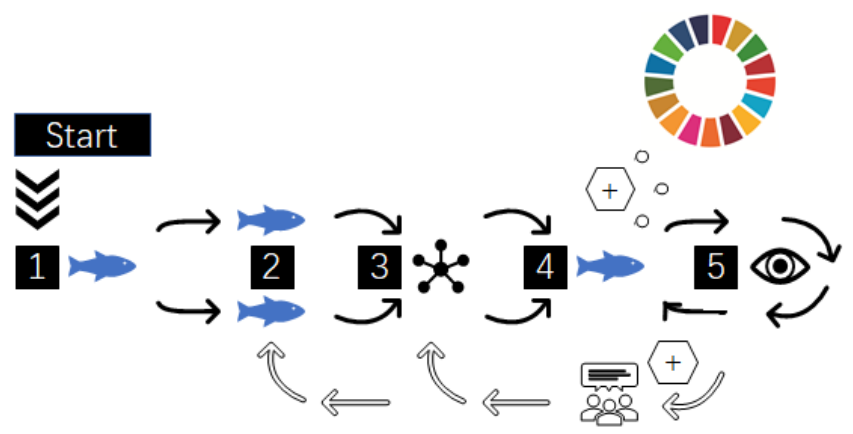

(a) Five-step process from assessment (step 1) to adaptive management implementation (step 5). Refer to manuscript text for further description and examples

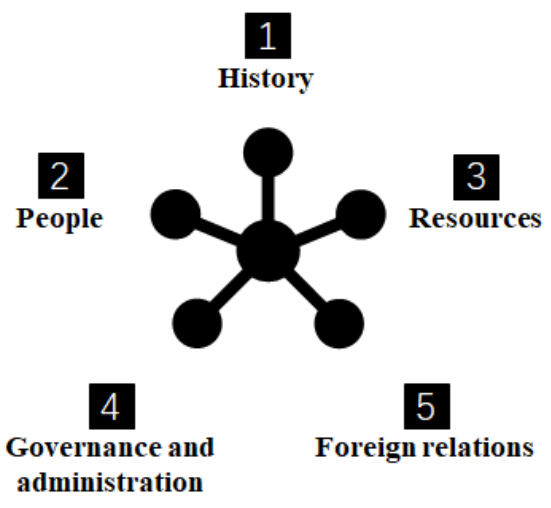

(b) Five principal correction factor themes

Figure 3. Schematic diagram of key processes and components in the proposed design, development and implementation of an improved resource management plan (a) and correction factors to be considered when adapting case studies and recommendations (b). The UN SDG (https://www.un.org/sustainabledevelopment/) colour wheel has been used with permission. The content of this publication has not been approved by the United Nations and does not reflect the views of the United Nations or its officials or Member States

(3) Regarding resources, beyond the abundance and distribution of marine fish resources and related fishing gear and boats (and respective total emissions and emissions per $\mathrm{kg}$ fish catch [24]), a holistic management plan needs to consider access to non-marine calorie and protein sources, including road networks and transportation infrastructure, which could be currently limiting food distribution and production in Sierra Leone [50]. Additionally, the distribution of money may have cascading effects. For example, some suggest that inadequate investment in the fisheries sector in Sierra Leone at least partly explains the low quality and quantity of fish data, limiting its capacity to inform decisions [25]. Science and technology must be considered.

(4) Good governance (and its resourcing) is fundamental in the appropriate management of society, resources and international relations. Key actors may include governments and traditional leaders, and there may be several systems at play, including tribal systems. In Sierra Leone, focus on tribal and political issues may divert focus from the common suffering of poverty and hunger [11], and the blame for depleting fish stocks crisscrosses between stakeholders [51]. As the parent body, government has the authority to regulate different users of the marine fish resources, including foreign and domestic industrial and small-scale vessels.

(5) Foreign relations, as a correction factor in our proposed model, may include financial aid, international trade, and exploitation and fairness. Currently, Sierra Leone imports more than it exports, but could benefit from concerted efforts to boost production and sustainable use of marine and other agricultural products. Coastal communities feel that foreign vessels and industrial fishing fleets have played a large role in the reduction of fish stocks in Sierra Leone, because of their choice of fishing gear (e.g., trawl nets) which have high levels of bycatch and discards, and their illegal fishing within the inshore economic zone (IEZ) intended for small-scale fishers [25]. There is clearly much to be done in Sierra Leone to ensure fairness, including effective enforcement of international laws, and reconciling relationships among users, managers, and authorities engaged in marine fishing.

\subsection{Principal needs and solutions for Sierra Leone}

\subsubsection{Policy solutions}

Countries that want to develop should not only have good policies, but also effective implementation backed up by good institutions and recognise development as a process [52-54]. From the administrative point of view in Sierra Leone, the institutions in the country are not working effectively or, one may say, the institutions are not well equipped either because of rampant corruption in the country or bad governance [10].

In order to achieve good results from their policymaking, such as increasing food security, the below points may benefit Sierra Leone. Furthermore, if laws and their implementation are fully realised, effects may also transcend to other countries around the world who will follow the demonstrated methods, as Sierra Leone, too, can do from present leaders [55-57].

(1) Develop as a formidable government which guarantees the effective implementation of regulations through inspection from parliamentarians, and monitoring and punishment by the authorities of people who violate these laws [58].

(2) Government should use laws to protect the environment. For example, fishing vessels should understand and adhere to agreed conditions and limits, including types of fishing lines and equipment [59]. This is to avoid degradation and destruction, as was seen in the 1970s during the period of diamond mining and trade in the absence of strong environmental protection laws [10, 28, 60-63].

(3) Government officials should carefully listen to the recommendations of both national and international expertise on science, policy making, and sustainable development goals.

(4) To address IUU and overfishing, the MFMR - through the central government - should put a hold on fishing for at least two months every year, similar to April 2019, and monitor effects as part of adaptive management [33], and/or establish 'no take' zones in MPA core areas to increase productivity and regulate fishing of 'spillover' in buffer zones.

Embedded in policies should be the involved working with traditional knowledge systems concerning ways of fishing [52].

\subsubsection{Technology solutions}

Sierra Leone is presently lacking in science and technology [64]. To advance in this area they should start with the cuttingedge tools already available at their disposal. In Sierra Leone, 
these are traditional practices and cultures, and modern technologies such as mobile phones. Countries rich in science and technology such as the UK and China started from somewhere $[64,65]$ and today can utilise new technologies capable of data management and the mapping and monitoring fish populations and environmental conditions, including early warning weather systems for safeguarding fisherman [66].

Concerning marine vessels, Sierra Leone is not a rich country and cannot afford to buy or produce ships by themselves. Motorised boats with large engines are needed to effectively patrol the sea, providing workers with the means to properly police the ocean for intruders and illegal activities among both international and domestic vessels [66]. For patrol boats and observers to have reliable communications with authorities, GPS and phone technology should be upgraded, extending signal coverage and network strength. There is also need to introduce new technology such as sophisticated cameras to record events happening in the ocean, such as IUU fishing in the Exclusive Economic Zone [67].

\subsubsection{Economics solutions}

Marine fisheries boost Sierra Leone's GDP, accounting for about 10 percent [27]. The fisheries sector provides economic income through revenue collection for the government and coastal fishermen [68]. Exports account for the majority of marine sector income due to international currencies [28, 69], though there are clearly needs to urgently rectify failing agreements so as to optimise economic gain. For example, in international trade relationships, foreign countries may disproportionately benefit and overexploit the resources and economics of developing countries [37]. Furthermore, as fish catch data for the industrial sector is reported by on-board observers who are paid by vessel owners rather than by government, data accuracy is deemed questionable [25]; a suitable remedial response might therefore, be for the government to recruit, train and safeguard on-board observers, increasing data quality and the likelihood of making effective and appropriate evidence-based decisions.

Diversification presents an economic pathway to sustainability [70]. Marine fisheries, aquaculture, agriculture, forestry, and mineral extraction all have potential to be productive sectors if the government manages and resources them well, removing the country out of poverty [71]. Investing in food diversity by sustainable organic and regenerative agriculture also alleviates dependence on marine fisheries and foreign imports [72], awarding government loans to local farmers (particularly women and youth $[68,73]$ ) and building skills and capacity to transition from household subsistence to national sustenance [4, 74]. As an integrated systems-level sustainability strategy, it is important to consider and counter potential rebounds and unintended negative consequences of any reduction in fish catch, such as overexploitation of forest animals and plants $[75,76]$, and also recognize the emissions of different agriculture and livestock product options [23].

\section{CONCLUSION}

Sierra Leone was very much development-oriented during the colonial rule, but immediately after gaining independence, the landscape of the political history changed. The governance system became corrupted, coupled with eleven years civil war. Institutional records were burnt to ashes, and today it is difficult to gather accurate data for research analyses. We recognise data availability as a limitation of this work and encourage the increased collection and publication of scientific data of resource monitoring and use, and sharing of knowledge and experience to support improved management.

In light of these difficulties, we have presented data of fish catch and access, local and international trade, and marketplace waste and community challenges, including data derived from a globally trusted organisation, the FAO and responsible national institution, MFMR. These data reveal that marine fish exports from 1976 to 2018 were consistently low in comparison to total catch (excluding the period of the civil war), despite the near four-fold higher catch in the most recent decade than in the 1970s, 1980s and 1990s. In both 2016 and 2019, China, Ghana and South Korea were among the highest importers of marine fish from Sierra Leone, representing principal trade flows. CPUE has evidently fluctuated over time and we suspect the reduction between 1999/2000 and 2010 is likely related with the three-fold increase in total catch over this period. We encourage the continuation of regular standardized CPUE measurements, or fish stock assessments, including to detect effects of management interventions such as fishing bans, thereby better guiding policy and practice to benefit present generations and those yet unborn. This includes attention to the contribution of different catch sources (e.g., legal foreign, legal domestic, and illegal), the data potentially aiding conflict resolution and appropriate targeted strategies.

This work contributes to a growing field of research in Sierra Leone, and newly documents the local-level access challenges and economic importance of marine fish capture and trade. The results help to clarify for the MFMR and central government that the marine resources could be better protected and utilized, and give confidence that it can take advantage of existing expertise and interpret how science, knowledge and policies can be effectively implemented to achieve sustainability in Sierra Leone: socially, economically, and environmentally. Acknowledging that the human population is still increasing, and that climate change and current fishing practices are leading to reduced ocean productivity, the needs for restoration, sustainable use, and diversification are of particular essence in order to eradicate hunger and poverty.

Beyond the broad range of recommendations offered in this article for readers who face similar development challenges as those in Sierra Leone, as well as case studies and a demonstration of how these may be adapted to fit the needs of other developing countries and management units, we emphasise three principal priorities to increase food security and the sustainability of marine fish resources in Sierra Leone:

(1) Enforce strong policies which protect the marine ecosystem, such as a deliberate and effective control of IUU fishing and use of illegal fishing gear, even if unpopular in the short-term.

(2) Harmonise government and community fishing organisations as a single union to represent and be responsible for fishing communities and interests.

(3) Provide government employment opportunities for a greater proportion of workers as observers on fishing vessels, safeguard and train them, and yield quality data which can further guide improved, effective and sustainable use of marine fish resources.

\section{ACKNOWLEDGMENT}

We would like to thank God and the Government of Sierra 
Leone (GoSL), Chinese Scholarship Council (CSC), and Northeast Forestry University, Harbin, China, for giving us this opportunity to develop our human capital, which is education. We would like to thank the anonymous people in the MFMR for providing us data and the anonymous reviewer for helping us to improve the manuscript.

\section{REFERENCES}

[1] Okafor-Yarwood, I. (2019). Illegal, unreported and unregulated fishing, and the complexities of the sustainable development goals (SDGs) for countries in the Gulf of Guinea. Marine Policy, 99: 414-422. https://doi.org/10.1016/j.marpol.2017.09.016

[2] United Nations (UN). (2015). Historic New Sustainable Development Agenda Unanimously Adopted by 193 UN Members, United Nations Sustainable Development Sumit 3. https://doi.org/10.1016/j.procs.2015.07.557

[3] Verbeke, W., Vanhonacker, F., Sioen, I., Van Camp, J., De Henauw, S. (2007). Perceived importance of sustainability and ethics related to fish: A consumer behavior perspective. Ambio: A journal of the Human Environment, 36: 580-585. https://doi.org/10.1579/0044-

7447(2007)36[580:PIOSAE]2.0.CO;2

[4] Gerten, D., Heck, V., Jägermeyr, J., Bodirsky, B.L., Fetzer, I., Jalava, M., Kummu, M., Lucht, W., Rockström, J., Schaphoff, S., Schellnhuber, H.J. (2015). Feeding ten billion people is possible within four terrestrial planetary boundaries. Nature Sustainability, 3(3): 200-208. https://doi.org/10.1038/s41893-019-0465-1

[5] Cheung, W.W.L., Lam, V.W.Y., Sarmiento J.L., Kearney, K., Waston, R., Zeller, D., Pauly, D. (2010). Large-scale redistribution of maximum fisheries catch potential in the global ocean under climate change. Global Change Biology, 16: 24-35. https://doi.org/10.1111/j.1365-2486.2009.01995.x

[6] Ramírez-Monsalve, P., Raakjær, J., Nielsen, K.N., Santiago, J.L., Ballesteros, M., Laksá, U., Degnbol, P. (2016). Ecosystem Approach to Fisheries Management (EAFM) in the EU - Current science-policy-society interfaces and emerging requirements. Marine Policy, 66: 83-92. https://doi.org/10.1016/j.marpol.2015.12.030

[7] Zhang, Y., Zhou, X., Lei, W. (2017). Social capital and its contingent value in poverty reduction: Evidence from Western China. World Development, 93: 350-361. https://doi.org/10.1016/j.worlddev.2016.12.034

[8] United Nations, Department of Economic and Social Affairs, Statistics Division, https://countryprofiles.unstatshub.org, accessed on Sept. 9, 2020.

[9] Pandza, K., Thorpe, R. (2009). Creative search and strategic sense-making: Missing dimensions in the concept of dynamic capabilities. British Journal of Management, 20 : https://doi.org/10.1111/j.1467-8551.2008.00616.x

[10] Marks, Z. (2019). Rebel resource strategies in civil war: Revisiting diamonds in Sierra Leone. Political Geography, $\quad$ 75: 102059 https://doi.org/10.1016/j.polgeo.2019.102059

[11] Alie, J.A.D. (2010). Roadmap to Independence: 1945-61. In: Alie, J.A.D. (eds) Sierra Leone Since Independence. History of a Postcolonial State, New Edition. Africa Future Publishers, Freetown, Sierra Leone.
[12] Ibrahim Koroma, S. (2018). Implementation of the voluntary guidelines on responsible governance of tenure and on sustainable small-scale fisheries in the fisheries and aquaculture legislation in Sierra Leone. Food And Agricultural Organization. United Nations, 94: https://doi.org/10.1017/CBO9781107415324.004

[13] FAO/CECAF Working Group. (2008). Report of the FAO/CECAF Working Group on the Assessment of Demersal Resources - Subgroup South, Rome, Italy.

[14] Jalloh, A.B., Sasaki, K., Thomas, M.O., Jalloh, Y. (2013). The geology, mineral resources of Sierra Leone and how the resources can be used to develop the nation. Procedia Earth and Planetary Science, 6: 131-138. https://doi.org/10.1016/j.proeps.2013.01.018

[15] Solís, D., Agar, J.J., del Corra, 1.J. (2020). Diversification, efficiency and productivity in catch share fisheries. Fisheries Research, 226: 105532. https://doi.org/10.1016/j.fishres.2020.105532

[16] Stead, S.M. (2018). Rethinking marine resource governance for the United Nations Sustainable Development Goals. Current Opinion Environmental Sustainability, 34: 54-61. https://doi.org/10.1016/j.cosust.2018.12.001

[17] Fao, F. (2018). The State of World Fisheries and Aquaculture - Meeting the sustainable development goals, Rome, 2018.

[18] United Nations. (1959). Economic and social council. International Organisation, 13: 569-582. https://doi.org/10.1017/S0020818300009346

[19] Antonova, A.S. (2016). The rhetoric of "responsible fishing": Notions of human rights and sustainability in the European Union's bilateral fishing agreements with developing states, Marine Policy, 70: 77-84. https://doi.org/10.1016/j.marpol.2016.04.008

[20] Free, C.M., Thorson, J.T., Pinsky, M.L., Oken, K.L., Wiedenmann, J., Jensen, O.P. (2019). Impacts of historical warming on marine fisheries production. Science, 363(6430): 979-983. https://doi.org/10.1126/science.aau 1758

[21] IPCC. (2019). Summary for Policymakers. In: Pörtner, H.O., Roberts, D.C., Masson-Delmotte, V., Zhai, P., Tignor, M., Poloczanska, E., Mintenbeck, K., Alegría, A., Nicolai, M., Okem, A., Petzold, J., Rama, B., Weyer N.M. (eds). IPCC Special Report on the Ocean and Cryosphere in a Changing Climate. In press.

[22] IPCC. (2021). Summary for Policymakers. In: MassonDelmotte, V., Zhai, P., Pirani, A., Connors, S.L., Pean, C., Berger, S., Caud, N., Chen, Y., Goldfarb, L., Gomis, M.I., Huang, M., Leitzell, K., Lonnoy, E., Mathews, J.B.R., Maycock, T.K., Waterfield, T., Yelekci, O., Yu, R., Zhou, B. (eds). Climate Change 2021: The Physical Science Basis. Contribution of Working Group I to the Sixth Assessment Report of the Intergovernmental Panel on Climate Change. Cambridge University Press. In press.

[23] Parker, R.W.R., Blanchard, J.L., Gardner, C., Green, B.S., Hartmann K., Tyedmers, P.H., Watson, R.A. (2018). Fuel use and greenhouse gas emissions of world fisheries. Nature Climate Change, 8: 333-337. https://doi.org/10.1038/s41558-018-0117-x

[24] Greer, K., Zeller, D., Woroniak, J., Coulter, A., Winchester, M., Palomares, M.L.D., Pauly, D. (2019). Global trends in carbon dioxide $\left(\mathrm{CO}_{2}\right)$ emissions from fuel combustion in marine fisheries from 1950 to 2016. 
Marine $\quad$ Policy, 103382 https://doi.org/10.1016/j.marpol.2018.12.001

[25] Okeke-Ogbuafor, N., Gray, T. (2021). Interpreting perceptions about coastal fisheries in Sierra Leone: Scapegoats and panaceas. Sustainability, 13(13): 7292. https://doi.org/10.3390/su13137292

[26] Fao, F. (2020). Fishery and Aquaculture Statistics. Global capture production 1950-2018 (FishstatJ). In: FAO Fisheries

Division www.fao.org/fishery/statistics/software/fishstatj/en.

[27] Seto, K., Belhabib, D., Mamie, J., Copeland, D., Vakily, J.M., Seilert, H., Baio, A., Harper, S., Zeller, D., Zylich, K., Pauly, D. (2017). War, fish, and foreign fleets: The marine fisheries catches of Sierra Leone 1950-2015. Marine Policy, 83: 153-163 https://doi.org/10.1016/j.marpol.2017.05.036

[28] Thorpe, A., Whitmarsh, D., Ndomahina, E., Baio, A., Kemokai, M., Lebbie, T. (2009). Fisheries and failing states: The case of Sierra Leone. Marine Policy, 33: 393400. https://doi.org/10.1016/j.marpol.2008.09.002

[29] Baio, A.C.M. (2009). Governance of the Marine Capture Artisanal Fisheries of Post-War Sierra Leone. Ph.D. dissertation. University of Portsmouth, U.K.

[30] Vakily, J.M., Seto, K., Pauly, D. (2012). The marine fisheries environment of Sierra Leone: belated proceedings of a national seminar held in Freetown, 2529 November 1991. Fisheries Centre, Vancouver, Canada.

[31] Sachs, J., Kroll, C., Lafortune, G., Fuller, G., Woelm, F. (2021). The Decade of Action for the Sustainable Development Goals: Sustainable Development Report 2021. Cambridge University Press, Cambridge. https://doi.org/10.1017/9781009106559

[32] MSC Fisheries Standard V2.01. (2018). Marine Stewardship Council, London, United Kingdom.

[33] Bah, U.U. (2019). Was Sierra Leone's one-month fishing ban enough to replenish fish stocks? https://news.mongabay.com/2019/07/was-sierra-leonesone-month-fishing-ban-enough-to-replenish-fish-stocks/ accessed on Sept. 19, 2020.

[34] 2015 Population and Housing Census Summary of Final Results. (2016). Statistics Sierra Leone, Freetown, Sierra Leone.

[35] Kuumuori, J., Afriyie, K., Yao, A. (2015). Microcredit: Empowerment and disempowerment of rural women in Ghana. World Development, 66: 335-345. https://doi.org/10.1016/j.worlddev.2014.08.027

[36] Sogn-Grundvåg, G., Asche, F., Zhang, D., Young, J.A. (2019). Eco-labels and product longevity: The case of whitefish in UK grocery retailing. Food Policy, 88: 101750. https://doi.org/10.1016/j.foodpol.2019.101750

[37] Okafor-Yarwood, I., Belhabib, D. (2020). The duplicity of the European Union Common Fisheries Policy in third countries: Evidence from the Gulf of Guinea. Ocean and Coastal Management, 184: 104953. https://doi.org/10.1016/j.ocecoaman.2019.104953

[38] Falk-Andersson, J., Berkhout, B.W., Abate, T.G. (2019). Citizen science for better management: Lessons learned from three Norwegian beach litter data sets. Marine Pollution Bulletin, 138: 364-375. https://doi.org/10.1016/j.marpolbul.2018.11.021

[39] Russi, D. (2020). Governance strategies for a successful marine protected area - The case of Torre Guaceto. $\begin{array}{llll}\text { Marine } & \text { Policy, } & 115 \text { : } & \end{array}$ https://doi.org/10.1016/j.marpol.2020.103849

[40] Sierra Leone's Second National Biodiversity Strategy and Action Plan 2017-2026. (2017). Government of Sierra Leone, Freetown, Sierra Leone.

[41] Malakar, K., Mishra, T., Patwardhan, A. (2019). Factors linked with adaptation in the Indian marine fishing community. Ocean and Coastal Management, 171: 37-46. https://doi.org/10.1016/j.ocecoaman.2018.12.026

[42] Barbièren, J., Heileman, S. (2016). Intergovernmental Oceanographic Commission - UNESCO's support for management of Large Marine Ecosystems. Environmental Development, 17: 349-352. https://doi.org/10.1016/j.envdev.2015.08.001

[43] Stewart, J., Callagher, P. (2011). Quota concentration in the New Zealand fishery: Annual catch entitlement and the small fisher. Marine Policy, 35: 631-646. https://doi.org/10.1016/j.marpol.2011.02.003

[44] Sumaila, U.R., Lam, V., Le Manach, F., Swartz, W., Pauly, D. (2016). Global fisheries subsidies: An updated estimate. Marine Policy, 69: 189-193. https://doi.org/10.1016/j.marpol.2015.12.026

[45] Aranda, M., Le Gallic, B., Ulrich, C., Borges, L., Metz, S., Prellezo, R., Santurtún, M. (2019). Research for PECH Committee - EU fisheries policy - latest developments and future challenges, European Parliament, Policy Department for Structural and Cohesion Policies, Brussels.

[46] Reilly, K., O’Hagan, A.M., Dalton, G. (2016). Moving from consultation to participation: A case study of the involvement of fishermen in decisions relating to marine renewable energy projects on the island of Ireland. Ocean Coastal Management, 134: 30-40. https://doi.org/10.1016/j.ocecoaman.2016.09.030

[47] Roberts, T., Jones, P.J.S. (2013). North East Kent European marine site: Overcoming barriers to conservation through community engagement. Marine Policy, 41: 33-40. https://doi.org/10.1016/j.marpol.2012.12.016

[48] United Nations Development Programme. (2021). About Sierra Leone UNDP in Sierra Leone, https://www.sl.undp.org/content/sierraleone/en/home/co untryinfo.html /accessed on Aug. 26, 2021.

[49] Okeke-Ogbuafor, N., Stead, S., Gray, T. (2021). Is inland aquaculture the panacea for Sierra Leone's decline in marine fish stocks? Marine Policy, 132: 104663. https://doi.org/10.1016/j.marpol.2021.104663

[50] Pushak, N., Foster, V. (2011). Sierra Leone's Infrastructure: A Continental Perspective. World Bank.

[51] Okeke-Ogbuafor, N., Gray, T. (2021). Is communitybased management of small-scale fisheries in Sierra Leone the answer to their problems? World Development Perspectives, 21: 100292. https://doi.org/10.1016/j.wdp.2021.100292

[52] Brownscombe, J.W., Adams, A.J., Young, N., Griffin, L.P., Holder, P.E., Hunt, J., Acosta, A., Morley, D., Boucek, R., Cooke, S.J., Danylchuk, A.J. (2019). Bridging the knowledge-action gap: A case of research rapidly impacting recreational fisheries policy. Marine Policy, 104: 210-215. https://doi.org/10.1016/j.marpol.2019.02.021

[53] Kinds, A., Sys, K., Schotte, L., Mondelaers, K., Polet, H. (2016). VALDUVIS: An innovative approach to assess the sustainability of fishing activities. Fisheries Research, 182:

158-171. 
https://doi.org/10.1016/j.fishres.2015.10.027

[54] Gustavsson, M. (2018). Examining the 'cultural sustainability' of two different ways of governing fishing practices. Marine Policy, 97: 262-269. https://doi.org/10.1016/j.marpol.2018.03.017

[55] Marriott, A., Brainerd, T.R. (1981). Sierra Leone, new directions in fisheries statistics. Marine Policy, 5: 72-73. https://doi.org/10.1016/0308-597X(81)90076-2

[56] Zeller, D., Booth, S., Davis, G., Pauly, D. (2002). Reestimation of small-scale fishery catches for U.S. flagassociated island areas in the western Pacific: The last 50 years, Fisheries Bulletin, 105(2): 266-277.

[57] Tanrattanaphong, B., Hu, B., Gan, C. (2020). The impacts of value chain upgrading on the export of processed food. Food Policy, 101906. https://doi.org/10.1016/j.foodpol.2020.101906

[58] Ponte, S., Kadigi, R.M.J., Mitullah, W. (2010). When the market helps: Standards, ecolabels and resource management systems in east African export fisheries. Global Agro-Food Trade Standards, 184-204. https://doi.org/10.1057/9780230281356 9

[59] Sei, S., Baio, A. (2018). Fisheries management in data deficient industrial fisheries of Sierra Leone: Input controls and ecological risk assessment. Proceedings of the Global Conference on Tenure and User Rights in Fisheries 2018: Achieving the Sustainable Development Goals by 2030, Yeosu, Republic of Korea.

[60] Bellows, J., Miguel, E. (2009). War and local collective action in Sierra Leone. Journal of Public Economics, 93: 1144-1157. https://doi.org/10.1016/j.jpubeco.2009.07.012

[61] Maconachie, R., Binns, T. (2007). "Farming miners" or "mining farmers"? Diamond mining and rural development in post-conflict Sierra Leone. Journal of Rural Studies, 23: 367-380. https://doi.org/10.1016/j.jrurstud.2007.01.003

[62] Le Billon, P. (2008). Diamond wars? Conflict diamond and geographies of resource wars. Annals of the Association of American Geographers, 98: 345-372. https://doi.org/10.1080/00045600801922422

[63] Richards, P., Chauveau, J. (2007). Land, agricultural change and conflict in West Africa: regional issues from Sierra Leone, Liberia and Côte d'Ivoire. Sahel and West Africa Club, Paris, France.

[64] Lu, J., Li, B., Li, H., Zhang, Y. (2020). Sustainability of enterprise export expansion from the perspective of environmental information disclosure. Journal of Cleaner Production, 252: 119839. https://doi.org/10.1016/j.jclepro.2019.119839

[65] Pita, P., Villasante, S., Arlinghaus, R., Gomes, P., Strehlow, H.V., Veiga, P., Vingada, J., Hyder, K. (2018).
A matter of scales: Does the management of marine recreational fisheries follow the ecosystem approach to fisheries in Europe? Marine Policy, 97: 61-71. https://doi.org/10.1016/j.marpol.2018.08.039

[66] Strong, J.A. (2020). An error analysis of marine habitat mapping methods and prioritised work packages required to reduce errors and improve consistency. Estuarine Coastal and Shelf Science, 240: 106684. https://doi.org/10.1016/j.ecss.2020.106684

[67] Fabinyi, M., Dalabajan, D. (2011). Policy and practice in the live reef fish for food trade: A case study from Palawan, Philippines. Marine Policy, 35: 371-378. https://doi.org/10.1016/j.marpol.2010.11.001

[68] World Bank, United Nations. (2012). Joint Reponse to youth employment in Sierra Leone.

[69] Driscoll, J., Tyedmand, P. (2010). greenhouse gas emission implications of fisheries management: The case of the new England Atlantic herring fishery, Marine Policy, 34: 353-359. https://doi.org/10.1016/j.marpol.2009.08.005

[70] Mania, E., Rieber, A. (2019). Product export diversification and sustainable economic growth in developing countries. Structural Change and Economic Dynamics, 51: 138-151. https://doi.org/10.1016/j.strueco.2019.08.006

[71] O’Neill, E.D., Asare, N.K., Aheto, D.W. (2018). Socioeconomic dynamics of the Ghanaian tuna industry: A value-chain approach to understanding aspects of global fisheries. African Journal of Marine Science, 40: 303-313. https://doi.org/10.2989/1814232X.2018.1513866

[72] Louhichi, K., Gomez, Y., Paloma, S. (2014). A farm household model for agri-food policy analysis in developing countries: Application to smallholder farmers in Sierra Leone. Food Policy, 45: 1-13. https://doi.org/10.1016/j.foodpol.2013.10.012

[73] ActionAid"s Strategic Plan "Just and Democratic Governance 2006-2010'. (2010). ActionAid, Johannesburg, South Africa.

[74] Cadzow, H., Binns, T. (2016). Empowering Freetown's women farmers. Applied Geography, 74: 1-11. https://doi.org/10.1016/j.apgeog.2016.06.010

[75] Okeke-Ogbuafor, N., Gray, T., Stead, S.M. (2019). Is there a 'wicked problem' of small-scale coastal fisheries in Sierra Leone? Marine Policy, 118: 103471. https://doi.org/10.1016/j.marpol.2019.02.043

[76] Okeke-Ogbuafor, N., Gray, T., Stead, M.S. (2018). The controversial role of foreign fisheries consultants in Sierra Leone's coastal waters. Marine Policy, 118: 18307036. https://doi.org/10.1016/j.marpol.2018.12.018 